\title{
Rural Farmers' Approach to Drought Adaptation: Lessons from Crop Farmers in Ghana
}

\author{
Hillary Dumba, Jones Abrefa Danquah, and Ari Pappinen
}

\section{Contents}

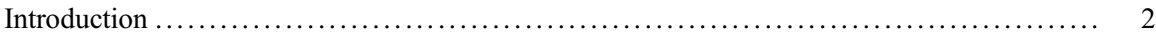

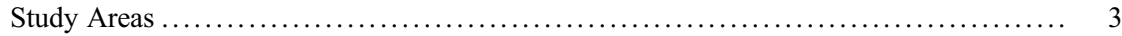

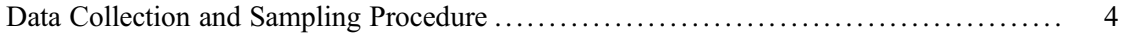

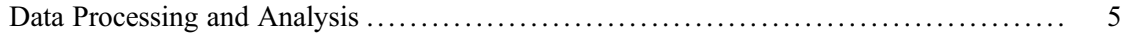

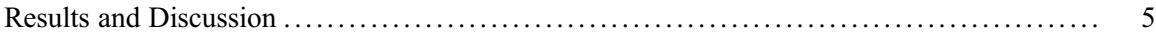

Farm Household Characteristics and Adaptation Capacity $\ldots \ldots \ldots \ldots \ldots \ldots \ldots \ldots \ldots \ldots .5$

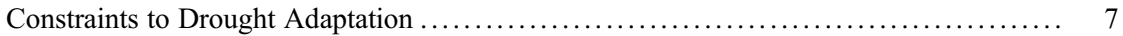

Determinants of Adoption of Drought Adaptation Measures . . . . . . . . . . . . . . . . 9

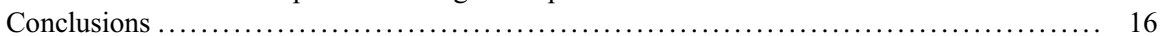

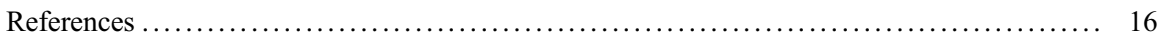

\section{Abstract}

Sub-Saharan Africa is considered to be highly vulnerable to climate changerelated disasters particularly drought. Farmers in Ghana have learnt to co-exist with it by resorting to various approaches. This study sheds light on farmers' adaptation to drought in Ghana. The cross-sectional survey design was used to

This chapter was previously published non-open access with exclusive rights reserved by the Publisher. It has been changed retrospectively to open access under a CC BY 4.0 license and the copyright holder is "The Author(s)". For further details, please see the license information at the end of the chapter.

\section{H. Dumba}

Institute of Education, College of Education Studies, University of Cape Coast, Cape Coast, Ghana

\section{J. A. Danquah $(\bowtie)$}

Department of Geography and Regional Planning, Faculty of Social Sciences, College of Humanities and Legal Studies, University of Cape Coast, Cape Coast, Ghana e-mail: jones.danquah@ucc.edu.gh
A. Pappinen
School of Forest Sciences, Faculty of Science and Forestry, University of Eastern Finland, Joensuu, Finland 
collect data from a random sample of 326 farmers and six purposively selected lead farmers from six farming communities. Questionnaire and in-depth interviews were used for data collection. The data were analyzed using descriptive and inferential statistics. The study revealed a significant variation between locations and use of drought adaptation approaches. The study showed that the most common drought adaptation measures comprise locating farms on riverine areas, drought monitoring, formation of farm-based organizations for dissemination of climate information, application of agro-chemicals, changing planting dates, cultivating different crops, integrating crop and livestock production, changing the location of crops, diversifying from farm to non-farm incomegenerating activities, and cultivation of early maturing crops. Therefore, it was recommended, among other things, that Non-Governmental Organizations (NGOs) should assist the government to construct small-scale irrigation facilities and provide drought-resistant crops to further boost the capacity of farming communities in Ghana.

\section{Keywords}

Rural Communities $\cdot$ Subsistence Farmers $\cdot$ Drought $\cdot$ Adaptive Capacity

\section{Introduction}

Climate change has occurred and still occurring. Among all climate change-induced disasters, drought is the costliest and most devastating climatic disaster that imposes untold adverse consequences on human activities. Its recurrent occurrence is associated with high level of vulnerability among farming households (Makoka 2008; United Nations 2010). It severely affects agriculture in rural areas as well as trade and food security in both developed and developing economies of the world. Drought is particularly hazardous to communities which depend on agriculture for livelihood (Diaz et al. 2016). Incidence of drought is prevalent in Ghana, with the 1983 being the severest and most destructive in the history of the country (Owusu and Waylen 2009). Drought conditions impose consequences on crop yield and food security (Van de Giesen et al. 2010). Previous report indicated that persistent drought conditions affected all investments in the agricultural sector in the country. Unreliable rainfall, prolonged droughts, coupled with high temperatures have severely affected sustainable agriculture in the country (Armah et al. 2011; Dietz et al. 2013). Ajzen's (1985) theory of planned behavior argues that individuals perform certain planned actions known as behaviors in response to the achievement of a target. Given the serious problems posed by drought to agriculture in Ghana, farmers practice adaptation to overcome or reduce the resultant vulnerability.

Families whose livelihoods depend on farming activities need a variety of adaptation strategies to mitigate the harmful impacts of climate change and. This will help them to maintain their livelihoods (Uddin et al. 2014). Adaptation serves as the means to mitigate a system's vulnerability to hazardous events. Adaptation 
reflects farmer's adaptive capacity. It is a process through which a society makes better adjustments and changes in order to adapt to an unforeseen situation in the future (Smit and Wandel 2006; United Nations Framework Convention on Climate Change (UNFCCC) 2011). Adaptation refers to the process of adjustment to the actual or expected climate, its variability, and concomitant effects (Intergovernmental Panel on Climate Change (IPCC) 2014; Quandt and Kimathi 2016). It is a means to build a system's capacity, resilience, and to adjust to the impact of climate change with the ultimate aim of reducing vulnerability. It is a process through which a society makes better adjustments and changes in order to cope with an unforeseen situation in the future (Smit and Wandel 2006). It may involve adjustments in technologies, lifestyles, infrastructure, ecosystem-based approaches, basic public health measures, and livelihood diversifications to reduce vulnerability (IPCC 2014). It may also serve as means to optimizing the potential benefits of climate change. Numerous studies have examined farmers' adaptation to climate change in different locations and contexts (Mabe et al. 2014; Obayelu et al. 2014; Shongwe et al. 2014). However, these studies are not only predominantly quantitative but also based broadly on farmers' adaptation to climate change. Farmers' adaptation to climate change is dependent upon specific climate change events and hence, may differ from one climatic event to another. The measures that farmers employ to adapt to other climate change events may differ from strategies employed to adapt to drought. Therefore, a clear understanding of farmers' adaptation to drought is desirable for designing and implementing appropriate drought adaptation strategies to enhance sustainable agriculture in Ghana. The study will expand theoretical knowledge and understanding of drought adaptation planning. Specifically, the study will shed more light on farmers' planned behavior towards drought. This will provide the necessary information and reference material for other researchers and drought management policy-makers. The study also explored only farmers' views on the use of both on-farms and off-farm measures to combat drought.

\section{Study Areas}

Three agro-ecological locations, namely, Wa West (Savannah zone), Nkoranza North (Transitional zone), and Wassa East (Forest zone) of Ghana were chosen as the sites for this study (Fig. 1). Evidence indicates that rain-fed agriculture constitutes the main livelihood activity in the selected agro-ecological locations. For instance, crop farming (96.1\%) is the major activity undertaken by households in the Wassa East District while most households (97.2\%) in the Wa West District are engaged in crop farming as the main economic activity. Similarly, almost all agricultural households (98.5\%) in the Nkoranza North District are involved in crop farming (Ghana Statistical Service 2013, 2014). 


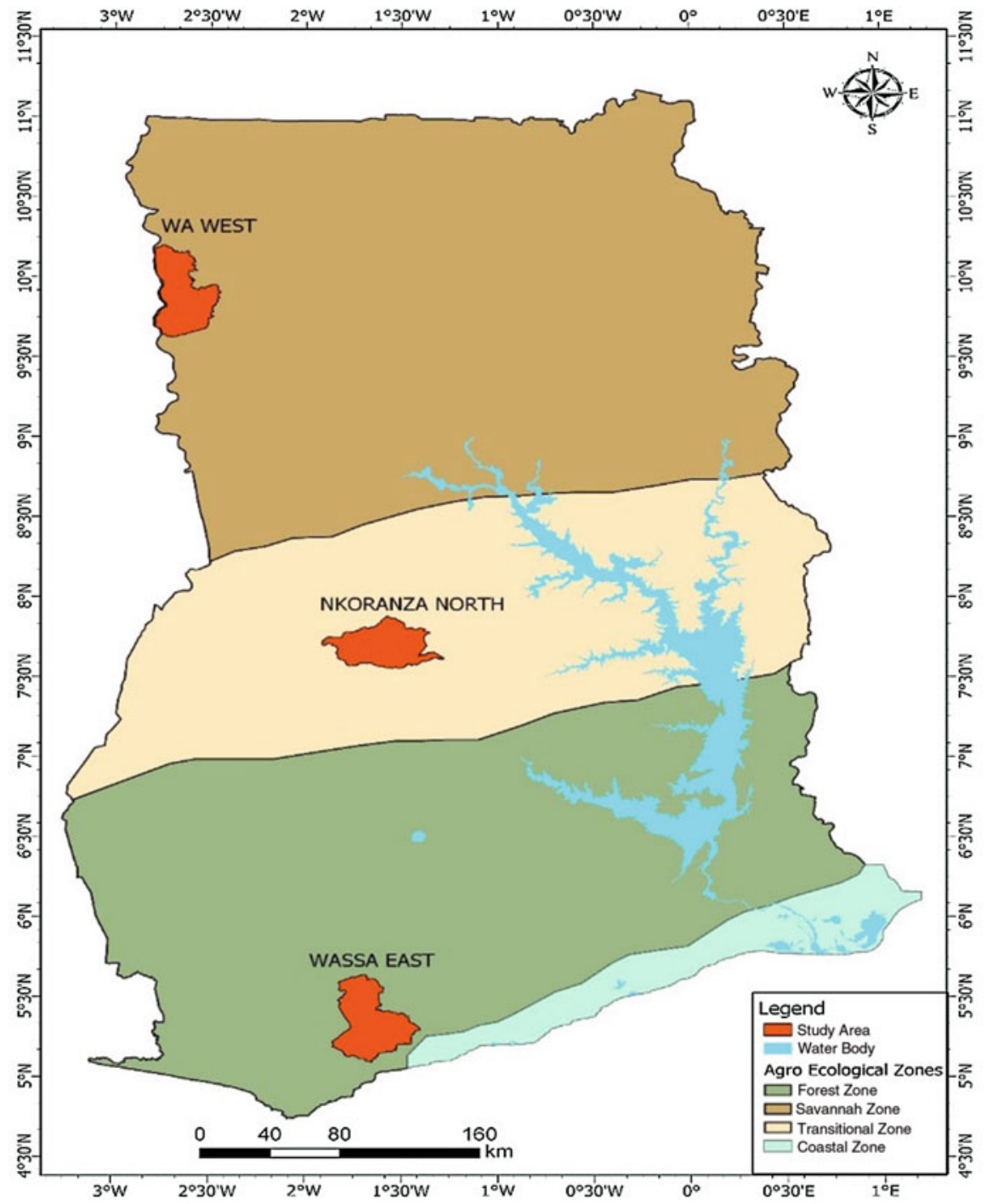

Fig. 1 Map of selected agro-ecological locations

\section{Data Collection and Sampling Procedure}

The study employed cross-sectional survey design because it has some practical advantages over longitudinal and experimental designs. Cross-sectional design helps to capture large factual numeric and descriptive data from a large sample that represents a wide target population on a one-shot basis (Bhattacherjee 2012). Out of a total population of 1765 household farmers, 326 participants were randomly selected using Yamane's (1967) formula. In generally, farming is a male-dominated 
activity in Ghana (Food and Agriculture Organization (FAO) 2012). However, harvesting, processing, and marketing is usually done by the female. Traditionally, the head of each household in these study areas is a male. However, in the absence of a male head the de facto female heads or de jure household heads were interviewed (See, Danquah 2015). Both qualitative and quantitative data were collected using structured questionnaire and in-depth interview guide.

\section{Data Processing and Analysis}

The first step in the process of analyzing qualitative data was data transcription. The tape recordings were listened to several times so as to get a complete sense of the data. All the transcribed data was categorized into patterns by following the guidelines prescribed by Miles and Huberman (1994) (cited in Cohen et al. 2011). Five points scale Likert estimation was used to assess or rate farmers' perception to sets of constraints to drought adaptation. The Likert scale ranging from "Strongly Disagree (5)" to "Strongly Agree (1)". We also employed Pearson Chi-Square Test Statistic Tool in the analyses. This helped to compare farmers' adaptation practices across the three selected agro-ecological zones. In addition, Phi and Crammer's V were generated as measures of contingency coefficient to explore the strength of the association between the agro-ecological zones and farmers' adaptation strategies (Prematunga 2012). Problem Confrontation Index (PCI) was used as modified procedure adopted from Elias (2015) and Talukder (2014), and was computed as follows:

$$
\mathrm{PCI}=\left[5\left(\mathrm{P}_{\mathrm{SA}}\right)+4\left(\mathrm{P}_{\mathrm{A}}\right)+3\left(\mathrm{P}_{\mathrm{N}}\right)+2\left(\mathrm{P}_{\mathrm{D}}\right)+\left(\mathrm{P}_{\mathrm{SD}}\right)\right]
$$

Where:

$\mathrm{P}_{\mathrm{SD}}=$ Frequency of farmers who rated the problem as strongly disagree

$\mathrm{P}_{\mathrm{D}}=$ Frequency of farmers who rated the problem as disagree

$\mathrm{P}_{\mathrm{N}}=$ Frequency of farmers who rated the problem as not sure

$\mathrm{P}_{\mathrm{A}}=$ Frequency of farmers who rated the problem as agree

$\mathrm{P}_{\mathrm{SA}}=$ Frequency of farmers who rate the problem as strongly agree

\section{Results and Discussion}

\section{Farm Household Characteristics and Adaptation Capacity}

We asked participants to indicate their level of formal education, age, years of schooling, farming experience, farm size, landholding, household size, and dependents (Fig. 2). The proportion of farmers in the Forest agro-ecological zone who obtained middle school education $(9.51 \%$.) is less than the proportion of farmers in Transitional agro-ecological zone with middle school education $(13.80 \%)$. This 


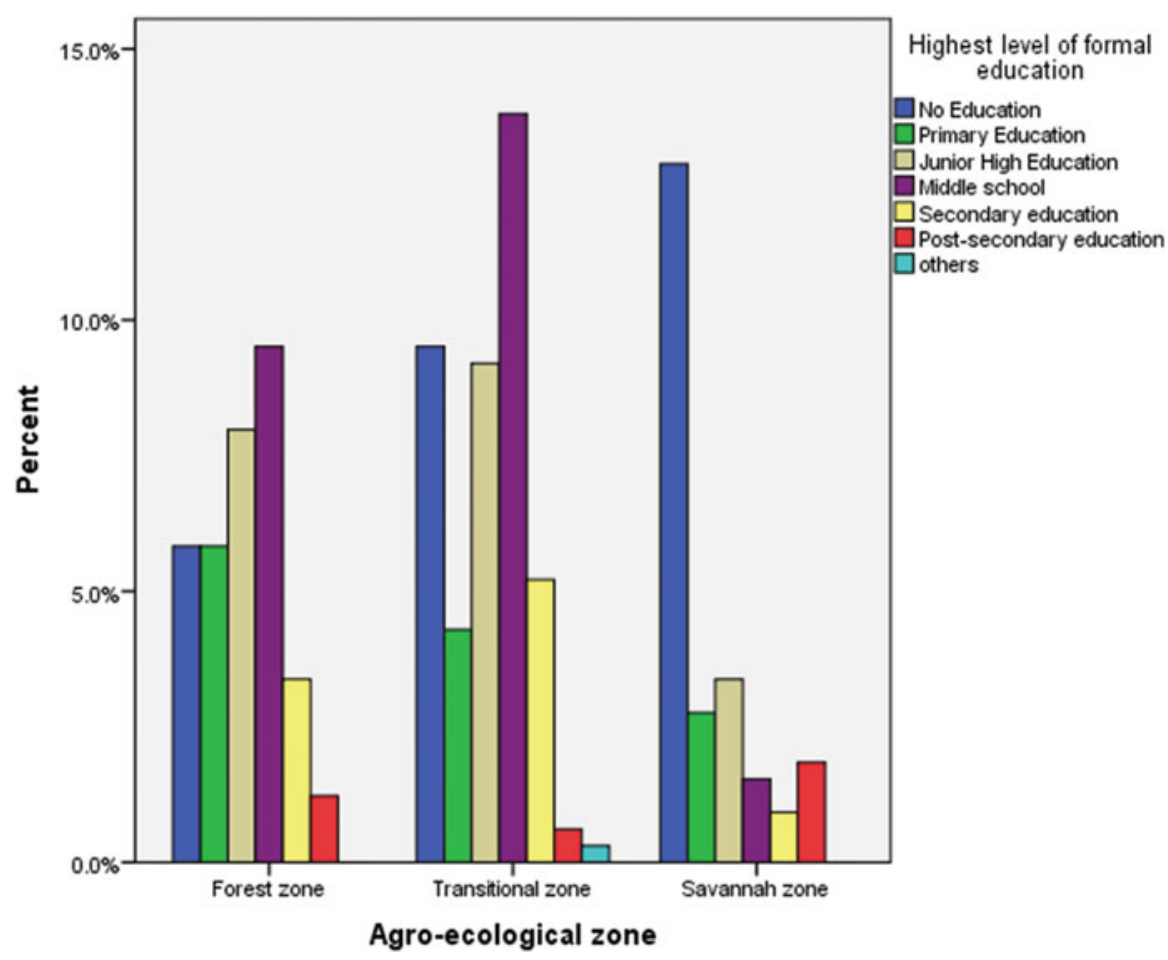

Fig. 2 Farmers' level of education across agro-ecological zones

Table 1 Descriptive statistics of farm household characteristics

\begin{tabular}{l|l|l|l|l|l}
\hline Variable & $N$ & Min & Max & Mean & SD \\
\hline Age (in years) & 326 & 18.00 & 87.00 & 43.99 & 14.12 \\
Years of schooling & 326 & 0.00 & 22.00 & 6.89 & 4.79 \\
\hline Farming experience (in years) & 326 & 1.00 & 76.00 & 18.96 & 13.45 \\
\hline Farm size (in acres) & 326 & 1.00 & 55.00 & 6.83 & 6.80 \\
\hline Landholding size (in acres) & 326 & 2.00 & 250.00 & 13.77 & 16.66 \\
\hline Household size & 326 & 1.00 & 25.00 & 6.37 & 3.56 \\
\hline Number of dependents & 326 & 0.00 & 10.00 & 2.83 & 2.08 \\
\hline
\end{tabular}

implies that most farmers in the Forest and Transitional zones had completed middle school compared to their farming counterparts in the Savannah zone where majority $(12.88 \%)$ had no education.

The educational background of farmers presupposes that these farmers would have knowledge and understanding of climatic events as well as climate change adaptation. According to Apata, (2011), education among farmers can promote climate change adaptation. Similarly, other empirical evidence from a study conducted by Abdul-Razak and Kruse (2017) indicated that farmers with formal 
education had high adaptive capacity while farmers without formal education had low adaptive capacity to cope with climate change and variabilities

The minimum age of the farmers was 18 years while the maximum age was 87 years (Table 1$)$. The mean age of the farmers was 43.9 years $($ Mean $=43.99$, $\mathrm{SD}=14.12$ ). Similarly, the result as shown in Table 1 is indicative that the participants have been farming for almost 19 years $($ Mean $=18.96, \mathrm{SD}=13.45$ ). Thus, the average farming experience is 18.96 years while the minimum and maximum years of farming experience are 1 year and 76 years, respectively. Farming experience contribute to the level of knowledge on climate change adaptation and risk management (Montle and Teweldemedhin 2014). It is also clear from the results that the selected farmers had an average of 6.83 acres (Mean $=6.83, \mathrm{SD}=6.80$ ).

Moreover, farmers had 1.0 acre and 55.0 acres as minimum and maximum farm size, respectively. It was revealed that most of the farmers who had large farms cultivated both cash and food crops. For instance, most farmers in the Forest zone planted vast acres of cocoa whereas some farmers in the Transitional zone cultivated cashew plants on large scale. The results show that farmers' farm estate landholding ranged from at least 2.0 acres to a maximum of 250 acres, with average landholding of 13.77 acres. This implies that access to land to undertake agricultural activities may not constitute a problem to the rural farmers (see, e.g., Kassaga and Kotey 2001).

The minimum and maximum household size were 1 and 25 persons, respectively. The average household size was found to be six (Mean $=6.37, \mathrm{SD}=3.56$ ) and the number of dependents in households ranged from zero to a maximum of 10 . Households had about three dependents on the average (Mean $=2.83$, $\mathrm{SD}=2.08$ ). Household size constitutes labor endowment of the farm household and it is an integration part of on-farm labor provision in smallholder farming systems (Deressa et al. 2009).

\section{Constraints to Drought Adaptation}

Farmers may have knowledge and information on drought adaptation. However, these farmers may not be capable of adapting to drought because certain factors that can hinder their adaptation behavior (see, e.g., Ajzen 1987, 2006). The results highlight that there are several challenges that confront farmers. It is evident from the results shown in Table 2 that a majority of 261 farmers (85.3\%) agreed that shortage of water for irrigation is problem that confronts their capacity to cope with the impacts of drought on their farming activities. The associated PCI indicates that shortage of water for irrigation ranks first among all the problems that farmers face. This situation can be attributed to the absence of major water sources coupled with reduced precipitation in the selected agro-ecological zones (Owusu and Waylen 2009). The shortage of water poses a challenge to farmers who would have otherwise wished to irrigate their farms during episodes of drought. This confirms results of a study by Abid et al. (2015) that shortage of water for irrigation is challenge that limits farmers adaptation to drought. Furthermore, the results indicate that out of the 


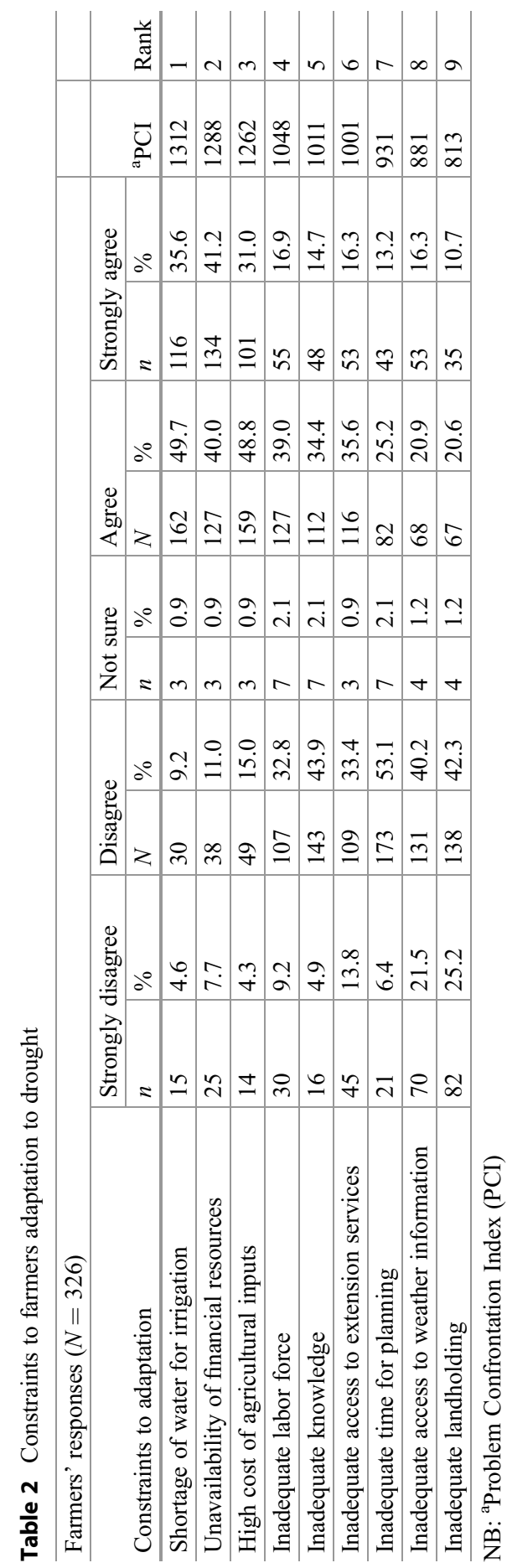


326 respondents, a majority of $85.3 \%$ farmers agreed that unavailability of financial resources serve as a constraint to their effort to adapt to drought (Table 2). This was ranked as the 2nd problem that confronts their capacity to adapt to drought. Lack of finance has been cited as the common problem that considerably hampers most farmers from adopting improved varieties of seed to combat drought (Fisher et al. 2015; Pardoe et al. 2016). High cost of agricultural inputs was rated or ranked 3rd and Inadequate labor force 4th by the farm household heads within the three ecological zones the study was conducted. However, farmers were least concern about access to land for their farming activities. This was ranked 9th on the list of factors influencing farm household ability to adapt to drought in the study area. Invariable, it was expected that extension education and information to weather forecast should feature prominently on top of the ranking, but turned out otherwise. Lack of agriculture extension services and climate base information in the form of weather forecast have been cited as the policy constraints to adaptation strategies of smallholder farmer in the tropics, particularly in sub-Saharan Africa including Ghana (Naab et al. 2019).

\section{Determinants of Adoption of Drought Adaptation Measures}

This section focuses on the presentation and discussion of main results on farmers' adoption or non-adoption of various drought adaptation measures. It also discusses farmers' socio-demographic factors as determinants of drought adaptation strategies. Table 3 presents the results with respect to farmers' drought adaptation across the three agro-ecological locations in Ghana. The application of agro-chemicals as a drought adaptation measure is significantly associated with agro-ecological locations as shown by the $\left.\left(\chi^{2}=43.98: \mathrm{DF}=2, N=326\right), p<0.001\right)$. It is indicative from the results that majority of farmers $(90.7 \%)$ in Nkoranza North in the Transitional zone applied agro-chemical compared to farmers in the Daboase and Wechaiu $(54.5 \%$ and $63.2 \%$, respectively) who adapted to drought through the application of agrochemicals. Most crop farmers in Daboase in the Transitional zone adopted the application of agro-chemicals compared to other farmers in the Forest zone because the Forest oxysol soil has higher moisture holding capacity and fertility and therefore more capable of supporting crop production. On the whole, the study reveals that most farmers (72.1\%) in the selected study areas adopted application of agrochemicals as measure to adapt to drought. This finding is consistent with results of previous studies that applying both organic and inorganic fertilizer on farmlands is a method of mitigating low crop yield associated with unreliable rainfall pattern and prolonged dry spell (Kurothe et al. 2014; Kloos and Renaud 2014; Pardoe et al. 2016).

The results as shown in Table 3 indicate that majority of farmers in Daboase in the Forest zone do not resort to migration as a drought adaptation measure. Out of the 110 farmers in the Forest zone who participated in the survey, an overwhelming majority of $101(91.8 \%)$ did not employ migration while only nine farmers $(8.2 \%)$ resorted to migration as a measure to reduce their vulnerability to drought. 


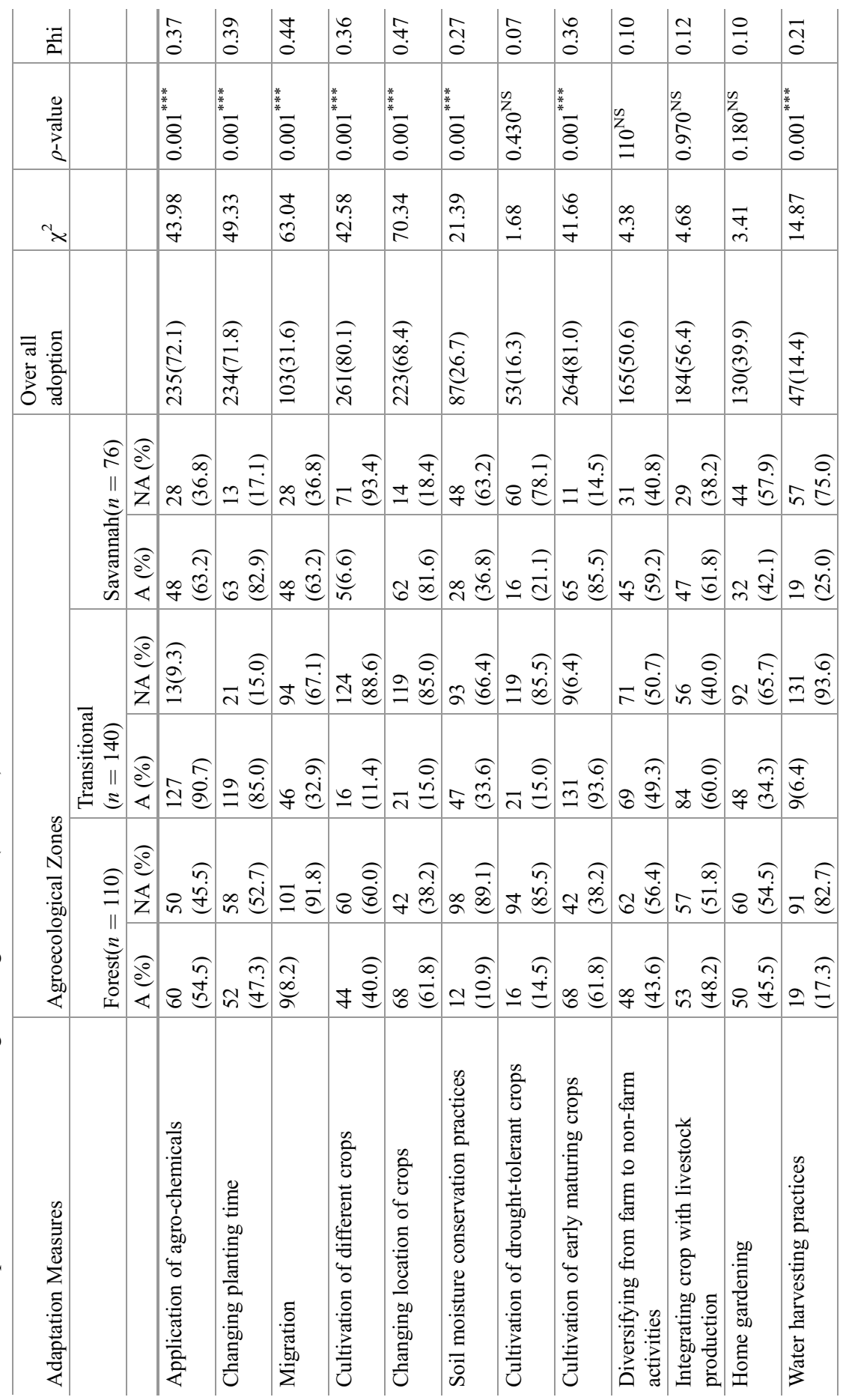




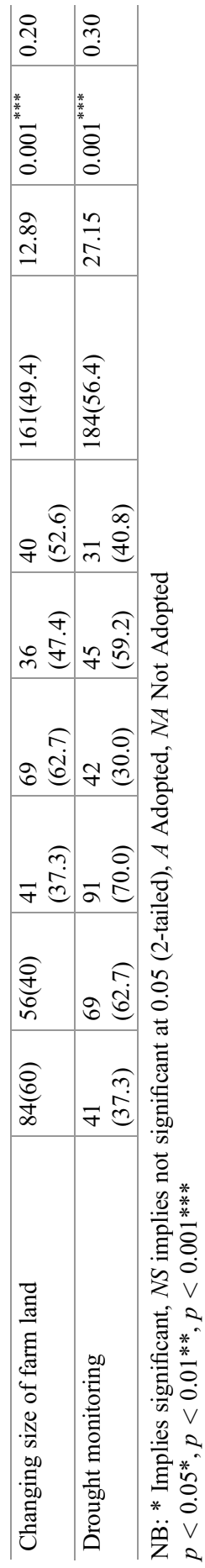


Moreover, out of the 140 farmers in Nkoranza North in the Transitional zone that participated in the study, it was found that a greater proportion of farmers $(67.1 \%)$ did not adopt migration as drought adaptation measure. Thus, migration is not a common drought adaptation strategy in the Forest as well as the Transitional zones of Ghana. This contradicts findings of Yang et al. (2015) that migration is the commonest drought adaptation strategy among farmers in the Ningxia Hui Autonomous Region of North-western China. Most farmers in the Forest and Transitional zones of Ghana do not adapt to drought through migration because there are various livelihood options and crop diversification strategies that assist them to adapt to the hardships imposed by drought (Asante et al. 2017). For instance, various artisanal activities, trading or business ventures, seeking employment in craft and cottage industries, and other sources of off-farm income generating abound in the forest belt of Ghana and hence, most farmers in this area do not over dependent on rain-fed agriculture. However, there are more cases of migration among farmers in Wechaiu in the Transitional zone compared to farmers in Daboase in the Forest zone (see Derbile et al. 2016). This is because some farmers in the Forest zone migrated either from the Savannah zone, Transitional zone, or neighboring communities in Cote d' Ivoire to undertake cocoa cultivation since the rainfall pattern in the Forest is more favorable to farming activities (Jarawura 2013).

The results suggest that farmers in the Savannah zone are more likely to adapt to drought and rainfall variability through migration to other places compared to farmers in the Forest and Transitional zones of Ghana. This collaborate the findings Van der Geest (2011) and Jarawura (2013), that rainfall variability and climate change slightly account for the out-migration of farmers from the three northern regions to Brong Regions of Ghana. When there are drought conditions some farmers migrate to other areas to engage in other livelihood activities. There is a statistical highly significant relationship between agro-ecological zones and farmers' adoption of migration as a drought adaptation measure $\left(\chi^{2}=63\right.$ : $\mathrm{DF}=2 ; N=326$; $p<0.001)$.

Migration among farmers is dependent on agro-ecological location. The phi value (0.44) indicates that is a positive significant moderate difference between farmers' migration patterns and agro-ecological zones. This is because the severity of drought differs from one agro-ecological zone to another (Adepetu and Berthe 2007).

The results indicated that out of the 110 farmers interviewed in Daboase in the Forest zone, $89.1 \%$ were nonadopters of soil moisture conservation practices as an adaptation strategy. However, relatively small proportion of the farmers $(10.9 \%)$ in this zone adopted soil conservation practices. Similarly, nonadopters were $66.4 \%$ and $63.2 \%$ in Transitional and Savannah zones respectively. Collectively, across all the ecological zones studied out of 326 farmers interviewed only 87 farmers employed soil conservation measures. This represents a total of $26.7 \%$ farmers.

Moreover, it was revealed that only 53 (16.3\%) out of the 326 farmers in the three agro-ecological zones cultivated some sort of drought-tolerant crops as drought adaptation measure. The results show that most farmers in the agro-ecological location do not cultivate crops that are drought-resistant. Only a small proportion of farmers in the various agro-ecological zones indicated that they cultivated some 
crops that are resistant to drought conditions. Farmers non-adoption of droughtresistant crop varieties can be attributed to the fact that most farmers in Ghana do not have access to drought-tolerant crops. This contradicts the results of previous works by Udmale et al. (2014) that rural farmers widely cultivate less water intensive and drought tolerant crops as adaptation options to drought.

The results show that a majority of 264 farmers (81.0\%) out of the 326 farmers in the three agro-ecological zones adopted the cultivation of early maturing crops as a measure to adapt to drought. The adoption of early maturing crops is highly dependent upon agro-ecological zone. Most farmers in the Savannah and Transitional zones cultivate early maturing crops compared to the proportion of farmers in the Forest zone who cultivate early maturing. The results of this current study corroborate the findings of various previous studies (Bawakyillenuo et al. 2016; Pardoe et al. 2016) that farmers resort to the cultivation of early maturing crops as a climate change adaptation strategy.

The study also revealed that farmers have been adapting to drought by integrating both farming and non-farming activities as similarly found by a previous study by Balama et al. (2013). From the results out of the 326 farmers, a little over half $(50.6 \%)$ diversified from farm to non-farm income generating activities in order to adapt to the impact of drought. Majority of farmers (59.2\%) who diversified farm to non-farm income generating activities were located in Wechaiu in the Savannah zone.

The study further indicated that most farmers (56.4\%) integrated livestock production with crop production as drought adaptation measure. This is because farmers seek solace in livestock rearing when their crops fail as a result of drought. Farmers do experience decline in crop productivity as a result of drought. Therefore, they have seen the need to engage in livestock rearing to augment their farming activities. Similarly, Balama et al. (2013) has found that local farmers in Kilombero District of Tanzania integrated crop farming into livestock production as a climate change adaptation strategy. The results in Table 3 indicate that most farmers in Wechaiu in the Savannah zone (61.8\%) as well as those in the Transitional zones $(60.0 \%)$ integrated livestock rearing with crop production compared to farmers in the Forest zone (48.2). This confirms results of a study by Bawakyillenuo et al. (2016) that integrating livestock rearing into crop production is common climate change adaptation method being adopted by farmers in rural Savannah zone of northern Ghana. This is because the vegetation and climatic features within the Savannah and Transitional zones are more favorable to livestock rearing compared to the Forest zone. However, this is not significant $\left(\chi^{2}=4.68: \mathrm{DF}=2, N=326 ; p>0.05\right)$.

There is moderate significant association between the proportion of farmers who employed water harvesting practices and agro-ecological zone $\left(\chi^{2}=14.87 ; \mathrm{DF}=2\right.$; $N=326, p<0.001)$. A majority of farmers $(93.6 \%)$ in the Transitional zone and farmers in Savannah $(75.0 \%)$ employed water harvesting practices as drought adaption measure compared to number of farmers in the Forest zone $(82.7 \%)$ who did not employ water harvesting practices to combat drought. Most farmers in the Savannah and Transitional zones experienced severe drought conditions and acute 
water shortage than farmers in the Forest zone (Armah et al. 2011). This in keeping with the fact that farmers in the Savannah and Transitional zones need to harvest rainwater and store it for domestic use and animal consumption as well. However, farmers in the Forest may have unimpeded access to riverine water supply throughout the year due to high level of precipitation (Armah et al. 2011).

The results show strong relationship between change in farm sizes and agroecological zones $\left(\chi^{2}=12.89\right.$; DF $\left.=2 ; N=326, p<0.001\right)$. Variation in farm size as a drought adaptation strategy is dependent upon agro-ecological location. The proportion of farmers who change their farm sizes as drought adaptation mechanism varies across the agro-ecological zones (sensu, Hansen et al. 2004). The settler farmers in the Transitional zone have fixed portions of land for farming, whereas the native farmers have most of their land occupied by cashew plantation. Hence, such farmers may find it difficult to increase their farm size. Farmers in the Savannah zone may not even change their farm sizes because fertile lands are limited in supply. Hence, farmers are fixated to the same parcel of land. Moreover, the farmers may find it unrewarding and time-consuming to clear new parcel of land for cultivation in the midst of unpredictable and scanty rainfalls. However, majority of farmers $84(60.0 \%)$ in Daboase in the Forest zone stated that they changed their farm sizes in order to deal with the impacts of drought. Finally, the results indicate that out of the 140 farmers in Nkoranza North in the Transitional zone, $70.0 \%$ in this zone adopted drought monitoring as drought adaptation strategy, particularly constant listen to weather news on radio and TV stations on daily basis. During an interview in the Transitional zone, a male farmer indicated that:

I always listen to 'weather man' on FM radio in order to know the on-set of rains before I even begin to prepare for farming. Sometimes before I go to farm, I have to listen to 'weather man' to know whether it would rain on that day or not (Male farmer, Transitional zone).

Similarly, a majority of 45 farmers $(59.2 \%)$ in the Savannah zone indicated that they employed drought monitoring as a tool for preparing for impending drought conditions and to improve their resilience to drought vulnerability. The plurality of radio stations as well as the availability of agricultural extension officers in the study areas provide easy access to weather information. Hence, most farmers continually monitor weather and climatic conditions before they plant their crops. Regarding drought monitoring, a lead farmer in the Savannah zone hinted during an interview schedule that:

We do not sow arbitrarily in this area. We usually 'study' the weather pattern to predict the arrival of rains before sowing seeds (Male lead farmer, Savannah zone).

However, majority of 69 farmers, representing $62.7 \%$ of the 110 farmers who participated in the survey in the Forest zone did not practice drought monitoring. The climatic conditions in this zone is quite conducive for agriculture. The farmers in this zone hardly experience severe drought that lasts long as compared to farmers in 
the Savannah and Transitional zones Moreover, the soil in the Forest zone holds moisture. Hence, farmers in this zone do not really have to monitor the rainfall pattern as farmers in the Savannah and Transitional zones would do. Overall, more than half of farmers (56.4\%) practice drought monitoring. This shows that drought monitoring is mostly being practiced by farmers as a method of adapting to drought in the selected agro-ecological zones. This confirms the results of a study by Pardoe et al. (2016) that farmers "follow the rain" until they are well-convinced that the rain would not fail them before they sow their seeds. It is obvious that drought monitoring is highly statistically and significantly related to agro-ecological zones $\left(\chi^{2}=27.15: \mathrm{DF}=2, N=326 ; p<0.001\right)$. This is because various agro-ecological zones have different amount of precipitation and soil moisture content to support farming activities. The phi value (0.30) indicates that there is a moderate significant relationship between drought monitoring and agro-ecological zones. Therefore, the decision of a farmer to monitor and time drought would depend upon a particular zone where he is located. Rather than employing only scientific and orthodox strategies to adapt to drought, the study also revealed that the farmers also employ prayers and supplications as means to adapt to drought conditions. They offer supplications to Him so that He would cause the rain to fall. This could be so because farmers have sociocultural perception about climate change and drought. Some farmers attribute the occurrence of climate and drought to the intention of God and other deities (Jarawura 2013). Hence, farmers combine both spiritual and scientific means to adapt to drought.

Traditionally, we usually call on deities to intercede for us to get the rains. We go round the community to pour libation asking the gods of the land to cause rains to fall. And if it rains, we thank them [gods] by making animal sacrifice. (Male farmer, savannah zone). During droughts, we throw a challenge to the gods of the land to let it rain to prove the that they are living gods (Male farmer, Transitional zone).

In conclusion, farmers employed both scientific and unscientific methods to adapt to drought in the selected agro-ecological locations in Ghana. The study reveals that drought adaption measures differ significantly among farmers in the Forest, Transitional and Savannah zones of Ghana. This finding is in harmony with results of various studies (Jarawura 2014; Abid et al. 2015; Bawakyillenuo et al. 2016) that climate and drought adaptation strategies are numerous and their implementation differs from place to place. This is because farmers' knowledge of drought adaption and their adaptive capacities as well as rainfall and soil properties differ from place to place. Therefore, farmers in various geographical locations would adapt to drought by adopting different mechanisms. However, the most commonly adopted drought adaptation measures comprise application of agro-chemicals, changing of planting date, cultivating different crops, integration of crop and livestock production, changing the location of crop on yearly basis, diversifying from farm to non-farm income generation activities, cultivation of early maturing crops, and drought monitoring. 


\section{Conclusions}

Farmers' adaptation to drought differs across various agro-ecological locations in Ghana and they adapt to drought by employing mixed adaptation strategies. The most commonly used drought adaptation strategies include application of agrochemicals, changing planting dates, cultivation of different crops, changing location of crops, cultivation of early maturing crops, diversification to non-farm activities, integrating crops and livestock production, as well as drought monitoring. Moreover, farmers' choice of specific drought adaptation strategies is a determinant of various factors. Farmers' ecological location acts as the major significant determinant of their adoption of all the eight drought adaptation measures. Finally, farmers with access to credit facilities and extension services are more likely to adopt farm-based drought adaptation measures and less likely to diversify to non-farming activities. Ministry of Food Agriculture (MoFA) and the National Disaster Management Organization should provide drought relief measures and safety net programs for vulnerable smallholder farmers. This also calls for the introduction and implementation of crop insurance schemes where farmers would be given the opportunity to indemnify their crops against possible loss associated with drought. As a matter of mitigating farmers' vulnerability to drought, both governmental organizations such as MoFA and National Climate Research Institute, and other non-governmental organizations should help develop, introduce, and implement affordable drought adaptation technologies in farming communities. The introduction and cultivation of drought-resistant crops, water harvesting, and conservative agriculture practices should be promoted among farmers in the country.

\section{References}

Abdul-Razak M, Kruse S (2017) The adaptive capacity of smallholder farmers to climate change in the northern region of Ghana. Clim Risk Manag 17:104-122

Abid M, Scheffran J, Schneider UA, Ashfaq M (2015) Farmers' perceptions of and adaptation strategies to climate change and their determinants: the case of Punjab province, Pakistan. Earth Syst Dyn 6:225-243

Adepetu AA, Berthe A (2007) Vulnerability of rural sahelian households to drought: options for adaptation. A final report submitted to assessments of impacts and adaptations to climate change (AIACC), Project No. AF 92. Retrieved from http://www.start.org/Projects/AIACC_Project/ Final Reports/Final

Ajzen I (1985) From intentions to actions: a theory of planned behaviour. In: Kuhl J, Beckmann J (eds) Action-control: from cognition to behaviour. Springer, Heidelberg, pp 11-39

Ajzen I (1987) Attitudes, traits, and actions: dispositional prediction of behaviour in personality and social psychology. In: Berkowitz L (ed) Advances in experimental social psychology. Academic, New York, pp 1-63

Ajzen I (2006) Theory of planned behaviour. Retrieved from http://people.umass.edu/ aizen/tpb. diag.htmlnull-link

Apata TG (2011) Factors influencing the perception and choice of adaptation measures to climate change among farmers in Nigeria. Evidence from farm households in Southwest Nigeria. Environ Econ 2(4):74-83 
Armah FA, Odoi JO, Yengoh GT, Obiri S, Yawson DO, Afrifa EKA (2011) Food security and climate change in drought-sensitive savannah zones of Ghana. Mitig Adapt Strateg Glob Chang 16(3):291-306

Asante WA, Acheampong E, Kyereh E, Kyereh B (2017) Farmers' perspectives on climate change manifestations in smallholder cocoa farms and shifts in cropping systems in the forest-savannah transitional zone of Ghana. Land Use Policy 66:374-381

Balama C, Augustino S, Eriksen S, Makonda FSB, Amanzi N (2013) Climate change adaptation strategies by local farmers in Kilombero District, Tanzania. Ethiop J Environ Stud Manag 6 (6):724-736

Bawakyillenuo S, Yaro JA, Teye J (2016) Exploring the autonomous adaptation strategies to climate change and climate variability in selected villages in the rural northern savannah zone of Ghana. Local Environ 21(3):361-382

Bhattacherjee A (2012) Social science research: principles, methods, and practices. University of South Florida, Tampa

Cohen L, Manion L, Morrision K (2011) Research methods in education, 6th edn. Routledge, New York

Danquah JA (2015) Analysis of factors influencing farmers' voluntary participation in reforestation programmes in Ghana. For Trees Livelihoods. https://doi.org/10.1080/14728028.2015.1025862

Derbile EK, Jarawura FX, Dombo MY (2016) Climate change, local knowledge and climate change adaptation in Ghana. In: Yaro J, Hesselberg J (eds) Adaptation to climate change and variability in rural West Africa. Springer, Cham. https://doi.org/10.1007/978-3-319-31499-0_6

Deressa TT, Hassan RM, Ringler C, Alemu T, Yesuf M (2009) Determinants of farmers' choice of adaptation methods to climate change in the Nile Basin of Ethiopia. Glob Environ Chang 19 (2):248-255

Diaz HM, Hurlbert M, Warren J (2016) Final research report of the rural communities' adaptation to drought. Canadian Plains Research Center, Regina. http://www.parc.ca/vacea/assets/PDF/ rcadrepor

Dietz T, van der Geest K, Obeng F (2013) Local perceptions of development and change in Northern Ghana. In: Yaro J (ed) Rural development in Northern Ghana. Nova Science Publishers, New York, pp 17-36

Elias AZM (2015) Farmers' problem confrontation in crop diversification at southern region of Bangladesh. J Agroecol Nat Resour Manag 2(3):230-233

Fisher M, Abate T, Lunduka RW, Asnake W, Alemayehu Y, Madulu RB (2015) Drought tolerant maize for farmer adaptation to drought in sub-Saharan Africa: determinants of adoption in eastern and southern Africa. Climate Change 133(2):283-299

Food and Agricultural Organization (2012) Gender inequalities in rural employment in Ghana: an overview. Retrieved from http://www.fao.org/docrep/016/ap090e/.pdf

Ghana Statistical Service (2013) Ghana living standard survey. Ghana Statistical Service, Accra

Ghana Statistical Service (2014) 2010 population and housing census: district analytical report. Nkoranza North. Ghana Statistical Service, Accra

Hansen J, Marx S, Weber E (2004) The role of climate perceptions, expectations, and forecasts in farmer decision making: The Argentine Pampas and South Florida. Final Report of an IRI Seed Grant Project. International Research Institute for Climate Prediction (IRI), The Earth Institute at Columbia University

Intergovernmental Panel on Climate Change (IPCC) (2014) Climate change 2014: impacts, adaptation, and vulnerability. Part B: regional aspects. Contribution of working group II to the fifth assessment report of the Intergovernmental Panel on Climate Change. Cambridge University Press, Cambridge

Jarawura FX (2013) Drought and migration in northern Ghana. Doctoral thesis, University of Ghana, Legon

Jarawura FX (2014) Perceptions of drought among rural farmers in the Savelugu district in the northern Savannah of Ghana. Ghana J Geogr 6:102-120 
Kassaga K, Kotey NA (2001) Land management in Ghana: building on traditional and modernity. International Institute for Environment and Development, London

Kloos J, Renaud FG (2014) Organic cotton production as an adaptation option in north west Benin. Outlook Agric 43(2):91-100

Kurothe RS, Kumar G, Singh R (2014) Effect of tillage and cropping systems on runoff, soil loss and crop yields under semiarid rain fed agriculture in India. Soil Tillage Res 140:126-134

Mabe FN, Sienso G, Donkoh S (2014) Determinants of choice of climate change adaptation strategies in northern Ghana. Res Appl Econ 6(4):75-94

Makoka D (2008) The impact of drought on household vulnerability: the case of rural Malawi. Paper presented at the 2008 United Nations University (UNU-EHS) Summer Academy on Environmental Change, Migration and Social Vulnerability. Retrieved from http://mpra.ub.unimuenchen.de/15399

Miles MB, Huberman AM (1994) An expanded source book: qualitative data analysis, 2nd edn. Sage, London

Montle BP, Teweldemedhin MY (2014) Assessment of farmers' perceptions and the economic impact of climate change in Namibia: case study on small-scale irrigation farmers (SSIFs) of Ndonga Linena Irrigation Project. J Dev Agric Econ 6:443-454

Naab FZ, Abubakarib Z, Ahmed A (2019) The role of climate services in agricultural productivity in Ghana: the perspectives of farmers and institutions. Clim Serv 13:24-32

Obayelu OA, Adepoju AO, Idowu T (2014) Factors influencing farmers' choices of adaptation to climate change in Ekiti state, Nigeria. J Agric Environ Int Dev 108(1):3-16

Owusu K, Waylen P (2009) Trends in spatio-temporal variability in annual rainfall in Ghana (19512000). Weather 64(5):115-120

Pardoe J, Kloos J, Assogba NP (2016) Seasonal variability: impacts, adaptations and the sustainability challenge. In: Yaro JA, Hesselberg J (eds) Adaptation to climate change and variability in rural West Africa. Springer International Publishing, Cham, pp 41-57

Prematunga RK (2012) Correlational analysis. Aust Crit Care 25:195-199

Quandt A, Kimathi YA (2016) Adapting livelihoods to floods and droughts in arid Kenya: local perspectives and insights. Afr J Rural Dev 1(1):51-60

Shongwe P, Masuku MB, Manyatsi AB (2014) Factors influencing the choice of climate change adaptation strategies by households: a case of Mpolonjeni Area Development Programme (ADP) in Swaziland. J Agric Stud 2(1):86-98

Smit B, Wandel J (2006) Adaptation, adaptive capacity and vulnerability. Glob Environ Chang $16: 282-292$

Talukder Md R (2014) Food security assessment in Sylhet Haor area emphasizing homestead productivity and agricultural resource utilization. A thesis submitted to Bangabandhu Sheikh Mujibur Rahman Agricultural University in partial Fulfillment of the requirement for the degree of Master of Science in agronomy. Sheikh Mujibur Rahman Agricultural University, Bangladesh

Uddin MN, Bokelmann W, Entsminger JS (2014) Factors affecting farmers' adaptation strategies to environmental degradation and climate change effects: a farm level study in Bangladesh. Climate 2:223-241

Udmale P, Ichikawa Y, Manandhar S, Shidaira H, Kiem AS (2014) Farmers' perception of drought impacts, local adaptation and administrative mitigation measures in Maharashtra State, India. Int J Disaster Risk Reduct 10:250-269

United Nations (2010) Natural hazards, unnatural disasters: the economics of effective prevention. World Bank, Washington, DC

United Nations Framework Convention on Climate Change (UNFCCC) (2011) Assessing climate change impacts and vulnerability: making informed adaptation decisions. Retrieved from www. unfecc.int/adaptation

Van de Giesen K, Liebe J, Jung G (2010) Adapting to climate change in the Volta Basin, West Africa. Curr Sci 98(8):1033-1037 
Van der Geest K (2011) The Dagara farmer at home and away. Migration, environment and development in Ghana. PhD dissertation, University of Amsterdam. African Studies Centre, Leiden

Yamane T (1967) Statistics: an introductory analysis, 2nd edn. Harper and Row, New York

Yang J, Tan C, Wang S, Wang S, Yang Y, Chen H (2015) Drought adaptation in the Ningxia Hui Autonomous Region, China: actions, planning, pathways and barriers. Sustainability 7:1502915056

Open Access This chapter is licensed under the terms of the Creative Commons Attribution 4.0 International License (http://creativecommons.org/licenses/by/4.0/), which permits use, sharing, adaptation, distribution and reproduction in any medium or format, as long as you give appropriate credit to the original author(s) and the source, provide a link to the Creative Commons license and indicate if changes were made.

The images or other third party material in this chapter are included in the chapter's Creative Commons license, unless indicated otherwise in a credit line to the material. If material is not included in the chapter's Creative Commons license and your intended use is not permitted by statutory regulation or exceeds the permitted use, you will need to obtain permission directly from the copyright holder.

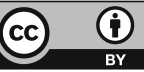

